7. Reprod. Fert. (1966) 11, 447-449

BRIEF COMMUNICATION

\title{
THE SPECIFIC GRAVITY OF BULL SPERMATOZOA AND SEMINAL PLASMA*
}

\author{
U. LAVON, R. VOLCANI, D. AMIR AND D. DANON $\dagger$ \\ Department of Animal Science, Volcani Institute of Agricultural Research, and \\ $\dagger$ The Weizmann Institute of Science, Rehovoth, Israel \\ (Received 3rd August 1965, revised 9th November 1965)
}

There are few reports in the literature concerning the specific gravity (s.G.) of mammalian spermatozoa and seminal plasma. Lindahl \& Kihlstrom (1952) using umbradil salts of methylglucamine as the suspending medium found bull spermatozoa to have a specific gravity of 1.241 to 1.335 . Lindahl \& Thunqvist (1965) using Ficoll (polysaccharide of sucrose) obtained values of 1.21 to 1.33 . These results are considerably higher than the specific gravity of 1.0975 reported by Yamane (1920) for the stallion, and 1.132 reported by Beatty (1964) for the rabbit. They also seem very high in view of the chemical composition of the dry matter and water content as given by Mann (1964) and VanDemark (1948).

The specific gravity of bull seminal plasma reported by Anderson (1946) was 1.0267 to 1.0392 ; he also obtained similar results for whole semen.

In the present study, the specific gravity of bull spermatozoa and seminal plasma was determined using the two-phase centrifugation method described by Danon \& Marikovsky (1964) for the determination of the density distribution of red cells. The validity of this procedure was previously tested by comparison with other methods.

Semen was collected from four Israel-Friesian bulls, 2 to $3 \frac{1}{2}$ years old. Five consecutive ejaculates were collected from each bull at 9-day intervals, using an artificial vagina. The semen was kept in thermos bottles at 30 to $35^{\circ} \mathrm{C}$ before analysis. Routine tests, including the determination of the number of spermatozoa and sperm motility by microscopic examination at $37^{\circ} \mathrm{C}$, showed that the semen was normal.

The specific gravity was determined within 1 to $2 \mathrm{hr}$ of collection. Samples from each of the five consecutive ejaculates were layered over a mixture of phthalate esters of increasing specific gravity at increments of 0.003 to 0.004 in capillary tubes of the type used in micro-haematocrit determinations. Each capillary was filled with a column of separating fluid to a height of about $8 \mathrm{~mm}$. The semen was then introduced by capillarity, leaving about $20 \mathrm{~mm}$ of the capillary unfilled. The dry end of the tube was sealed and the capillaries

* Contribution from the National and University Institute of Agriculture, Rehovoth, Israel. 1965 Series, No. 890-E. 
centrifuged. After centrifugation for $10 \mathrm{~min}$ at $12,000 \mathrm{~g}$, the cells with a specific gravity higher than that of the phthalate ester fluid in a particular capillary were found at the bottom, while cells of lower specific gravity were found on top of the non-aqueous fluid.

Separating fluids of specific gravities ranging from 1.043 to 1.118 were prepared by mixing di- $n$-butyl phthalate and di-ethyl-phthalate in the required proportions. For the preparation of fluids of lower specific gravity (down to 1.0258 ), mixtures of di- $n$-butyl phthalate and di-iso-butyl phthalate were used. The specific gravity of each mixture was determined by a pycnometer of $10 \mathrm{ml}$ capacity at $30^{\circ} \mathrm{C}$.

After centrifugation, the series of capillary tubes showed the specific gravity distribution of cells and seminal plasma as shown in Text-fig. 1 .

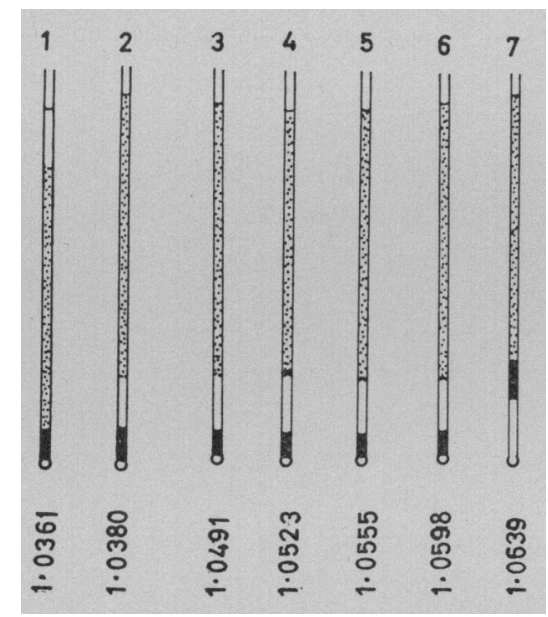

TExT-FIG. 1. Seven selected capillary tubes for the determination of the specific gravity of spermatozoa and of seminal plasma. In the first tube the separating fluid is just below the surface; in the second the fluid is between the plasma and the cells. Tubes 3, 4, 5 and 6 show a narrow ring of cells on top of the separating fluid and in tube 7 the specific gravity of the cells is lower than the separating fluid. The specific gravity of the nonaqueous separating fluid is given beneath each capillary tube.

The mean specific gravity of the spermatozoa in one ejaculate was calculated by the equation:

$$
\text { s.G. }=\frac{d_{1} \cdot X_{1}+d_{2} \cdot X_{2}+\cdots+d_{n} \cdot X_{n}}{100}
$$

where s.G. $=$ mean specific gravity.

$d_{1}$ to $d_{n}=\%$ of spermatozoa present on top of the non-aqueous layer in one capillary and not on top of the layer in the preceding tube, the tubes being arranged in ascending order of s.G.

$X_{1}$ to $X_{n}=$ average specific gravity of two consecutive separating fluids.

The results showed that the specific gravity of bull spermatozoa ranged from 1.0376 to 1.0927 . The specific gravities of spermatozoa in five consecutive ejaculates are given in Table 1. In three out of four bulls the specific gravity of the spermatozoa of the same bull tended to decrease from the first to the fifth 
consecutive ejaculate. These results are in close agreement with those obtained for stallion spermatozoa by Yamane (1920) and for rabbit spermatozoa by Beatty (1964). They are also in accordance with theoretical calculations obtained from dry matter content and chemical composition (see VanDemark, 1948; Mann, 1964). However, there is a pronounced difference between our results for the specific gravity of spermatozoa and those reported by Lindahl \& Kihlstrom (1952) and Lindahl \& Thunqvist (1965).

The average specific gravity of seminal plasma ranged from 1.0281 to 1.0421.

TABLE 1

SPEGIFIC GRAVITY OF SPERMATOZOA AND SEMINAL PLASMA IN EJAGULATES

(MEAN \pm S.E. IN FOUR BULLS)

\begin{tabular}{l|c|c|c|c|c}
\hline & \multicolumn{5}{|c|}{ Ejaculates } \\
\cline { 2 - 6 } & First & Second & Third & Fourth & Fifth \\
\cline { 2 - 6 } $\begin{array}{l}\text { Specific gravity } \\
\text { of spermatozoa }\end{array}$ & $1.0760 \pm 0.003$ & $1.0748 \pm 0.003$ & $1.0723 \pm 0.006$ & $1.0691 \pm 0.003$ & $1.0696 \pm 0.002$ \\
$\begin{array}{l}\text { Specific gravity } \\
\text { of seminal } \\
\text { plasma }\end{array}$ & $1.0381 \pm 0.0006$ & $1.0375 \pm 0.0006$ & $1.0371 \pm 0.0005$ & $1.0363 \pm 0.0005$ & $1.0344 \pm 0.0007$ \\
\hline
\end{tabular}

The values obtained in five consecutive ejaculates are given in Table 1. There was a distinct decline in specific gravity of the seminal plasma from the first to the fifth consecutive ejaculate for the four bulls.

The values for the specific gravity of seminal plasma obtained in this study are similar to those reported by Anderson (1946).

This research has been financed in part by a grant awarded by the United States Department of Agriculture under P.L. 480. This study is part of a work to be submitted by U.L. in partial fulfillment of the requirements for a Ph.D. from the Hebrew University, Jerusalem.

\section{REFERENCES}

Anderson, J. (1946) The buffer capacity and the specific gravity of bull semen. F. agric. Sci. 36, 258.

BeATty, R. A. (1964) Density gradient media for mammalian spermatozoa. $V$ Congresso Internazionale per la Riproduzione Animale e la Fecondazione Artificiale, Trento, vol. III, p. 276.

Danon, D. \& MARIKovsky, Y. (1964) Determination of density distribution of red cell population. F. Lab. clin. Med. 64, 668.

Lindahl, P. E. \& Kinlstrom, J. E. (1952) Alterations in specific gravity during the ripening of bull spermatozoa. F. Dairy Sci. 35, 393.

LindahL, P. E. \& Thungvist, L. O. (1965) Specific gravity of epididymal and ejaculated bull spermatozoa and of their parts. Experientia, 21, 94.

MANN, T. (1964) The Biochemistry of semen and of the male reproductive tract. Methuen, London.

VANDEMARK, N. L. (1948) The relation of spermatozoa metabolism and other semen characteristics to the livability of bovine spermatozoa in different nutrient diluters. Ph.D. thesis, Cornell University, Ithaca, New York.

Yamane, J. (1920) 7. Coll. Agric. Hokkaido imp. Univ. 9, 161 (cited by T. Mann 1964, p. 108). 